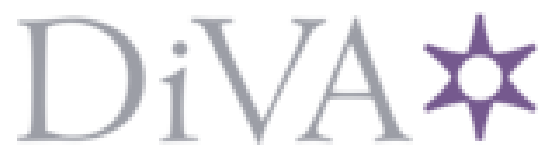

http://www.diva-portal.org

\title{
Postprint
}

This is the accepted version of a paper published in British Journal of Music Education. This paper has been peer-reviewed but does not include the final publisher proof-corrections or journal pagination.

Citation for the original published paper (version of record):

de Boise, S. [Year unknown!]

Gender Inequalities and Higher Music Education: Comparing the UK and Sweden.

British Journal of Music Education

Access to the published version may require subscription.

N.B. When citing this work, cite the original published paper.

Permanent link to this version:

http://urn.kb.se/resolve?urn=urn:nbn:se:oru:diva-61945 


\section{Gender Inequalities and Higher Music Education: Comparing the UK and Sweden}

\section{Sam de Boise}

School of Music and Theatre, Örebro University, Fakultetsgatan 1, Örebro, Sweden 70281

sam.deboise@oru.se

Whilst the impact of gender inequalities has been studied in relation to music education, especially in the UK, relatively little has been written about their impact on higher music education (HME). This article compares data on HME programs and courses, in the UK and Sweden, from 2010 to 2014. It looks at similarities and differences in the numbers of men and women who applied to HME subjects, compared to those who were offered a place on their chosen program or course, in both nations. Through this it demonstrates that whilst a Swedish HME appears to show less institutional discrimination against women, there are still similar transnational divisions in men's and women's HME subject choices. However the article uses these data to build on existing critiques around a need for intersectional understandings of gender inequalities, before arguing that a critique of neoliberalism is essential to tackling gender inequalities in HME.

Introduction

The subject of gender equality in music has long been a focus of feminist musicologists, music educationalists and musicians. In many Anglophone nations, especially, women's exclusion from music curricula (Citron, 1993; McClary, 1991), the marginalisation of women composers (Macarthur, 2014) from Western art music traditions, and the exclusion of women and girls from genre-oriented spaces (see Donze, 2010; Farrugia, 2012; Gavanas and Reitsammer, 2013) have been well-documented.

Gender equality in higher music education (HME) is particularly important in that, in neoliberal societies, universities are increasingly being seen as routes into professional music careers (Allsup, 2015). Who studies which music subjects will therefore impact on divisions in music professions and the music industries. Thus, inequalities in formal music education relate to and further impact on inequalities in wider music practices.

The UK, in particular, has come under scrutiny for its lack of attention to gender inequality in music education (Armstrong, 2011; Bogdanovic, 2015; Born \& Devine, 2015; Green, 1997). The inclusion of Fanny Mendelssohn on an A-Level exam paper in 2016, marks the first time ever a woman composer has been mentioned in music examinations in the UK. Yet in Sweden, too, there is an emerging discussion, about the extent to which gender inequalities also exist in music education (Bergman, 2014; Björck, 2013; Kvarnhall, 2015), despite being more structurally equal in many other respects (Nyberg, 2012). A critical look at HME in Sweden in comparison to other nations therefore has implications for conceptualising and tackling gender equality in music. 
This article examines and compares data on HME in the UK and Sweden, from 20102014. It looks at similarities and differences in the numbers of men and women who applied compared to those who were offered a place on programs and courses in both nations. The quantitative findings outlined here are indicative rather than definitive and as such are intended to raise questions around the conceptualisation of gender equality in $\mathrm{HME}$ and to inform future research. By using these two national contexts the article hopes to indicate the presence of transnational gendered discourses in HME. Through this, it intends to use existing critiques of the problems in treating equality in music as only a matter of quantitatively equal numbers of men and women.

The article begins by outlining similarities and differences between the nations in terms of gender equality and music education traditions. It then moves on to discuss the comparative datasets and the method used. It highlights overall gender differences in national level data and by subject area, before outlining the implications of the data for research on gender equality in music education. It does so with reference to an understanding of intersectionality and neoliberal agendas in higher education.

\section{Comparing Contexts}

In order to interpret the data, it is first necessary to contextualise similarities and differences between Sweden and the UK. By focusing specifically on gender equality, general music education and higher education, this will help to demonstrate to what extent data trends may be explained by national factors.

\section{Gender Equality}

Sweden has one of the highest gender equality scores of any OECD country (World Economic Forum, 2014) and is often seen as one of the most gender-equal nations in the world (Martinsson, Griffin \& Nygren, 2016). Despite a gender wage gap similar to that of the UK amongst those under 34 (U.N., 2014), the principle of gender equality, at least, is strongly related to Swedish national identities (Hearn et al., 2012, p. 33). Throughout the $20^{\text {th }}$ century, Swedish governments actively pursued policies aimed at fostering gender equality (Nyberg, 2012) and left and right (including extreme right) parties, today, claim to support gender equality agendas (Towns, Karlsson \& Eyre, 2014). This can be related to the Social Democratic party's 60 years of uninterrupted dominance in the Swedish Parliament, historical support for women's rights (Hearn, 2015, pp. 46-50) and direct statist interventions in equality agendas (Heclo, 2010).

By contrast, the UK has a long history of gender-segregated labour, and social policies geared toward 'male breadwinners' (Crompton, 2001). These changed slowly under New Labour, emerging largely out of economic concerns (Kilkey, 2006). Yet, following the 2008 recession, the Coalition government's austerity policies have disproportionately impacted on women, due in part to cuts to the public sector, childcare and increasing income inequalities (Women's Budget Group, 2016). Women are more likely to be in the lowestpaid jobs in the UK, which has one of the highest income inequalities in the OECD. Sweden, on the other hand, despite one of the fastest increasing inequalities as a result of market deregulation and privatisation from the 1980s onwards (Roine \& Waldenström, 
2012) has had one of the lowest income inequality levels throughout the $20^{\text {th }}$ Century (Piketty, 2014).

\section{General Music Education}

Educationally, the UK has a tiered school system divided into 'elite', fee-paying schools; state-subsidised, fee-paying schools; privately-run academies; and state-funded comprehensive schools (West, 2014). Sweden has had free education since 1842 and it still has no fee-paying, tax-payer funded schools, though it too has privatised 'free schools', on which England's 'academy' system is based (Arreman \& Holm, 2011). Gender-exclusive schools were formally abolished in Sweden in 1974 whereas, as of 2014, the UK still had 250. In both nations girls achieve higher grades than boys in standardised testing, in almost every subject. However, the 'attainment divide' in music is actually much closer than most other subjects (Gov.uk, 2016, Table 3.2(d)i; SCB 2015: 166).

A popular music curricula in secondary schools (gymnasium) was implemented in Sweden in the 1960s, as part of a social democratic reform agenda (Georgii-Hemming \& Westvall, 2010). In addition, children have been able to access free, or heavily subsidised, extracurricular music tuition via kulturskola (culture schools), which were formerly called kommunal musikskola (municipal music schools), since the 1940s. ${ }^{1}$ The UK, by comparison, has historically tended much more toward teaching formal theory and 'artistic' music education in secondary schools (Green 2002: 5). This also changed significantly under New Labour to include more practice-based methods (Hallam and Creech 2010). Though there has been a gradual reinstatement of formal music theory teaching since $2010 .^{2}$ There has also been a funding decrease, in real-terms, for extracurricular music funding, from c. $£ 110$ million in 2011/12 to c. $£ 75$ million in 2016/17. ${ }^{3}$ Private one-to-one tuition is instead often used to support children's musical development. Though due to the fact it is expensive, ${ }^{4}$ its utilisation is heavily linked to class background. ${ }^{5}$

Higher Music Education

Both nations have music conservatoires, but Swedish music education is different in several ways. HME courses and programs in Sweden are taught at 6 main conservatoires (musikhögskola) which are, for the most part, attached to universities; the main exception being Stockholm's Royal College of Music. On top of this, Sweden has a history of free, adult-education programmes implemented through folkhögskola (people's schools) which offer various forms of aesthetic and performance-related educations. These are heavily tied to uniquely Swedish folkbildning (people's education) traditions (for a definition and history of folkbildning, see Brändström et al. 2012). Secondly, there are far fewer universities overall ${ }^{6}$ and not every university has a music department or offers a musicrelated education. This is partly because Sweden has a population of only c.9,747,355 compared to c.64,596,752 in the UK. The UK, by contrast, has music departments, or offers HME programs, at most of the universities in the country, in addition to its 11 standalone music conservatoires.

Swedish university tuition is still paid for entirely by the state, whereas the UK's $£ 9,000$ tuition fees are mostly directly paid for through student loans or students' parents. Swedish 
universities are also still public institutions and as such they must legally abide by broader 'gender mainstreaming' agendas (Regeringskansliet 2014). For instance gender equality provisions outlined in the 1992 Higher Education Act (Ch. 1 Section 5) state that:

Equality between women and men shall always be taken into account and promoted in the operations of higher education institutions.

University students in Sweden are also generally slightly older when they start studying, owing to the fact that extended schooling finishes at 19 for most.

\section{Data and Analysis}

Many of the studies which have looked at gender inequality in music education, in both nations, have been focused on secondary schools and gymnasiaúm equivalents (Armstrong, 2011; Björck, 2013; Borgström-Källén, 2014; Green, 1997); with one key exception in the UK (Bogdanovic, 2015). These have all offered vital qualitative insights into the nature of gender inequality in music education. However it is also important to locate qualitative accounts within broader statistical trends in order to expand the scope of research on equality in music education (see Born \& Devine, 2015).

This article quantitatively compares national application and offer rates in $\mathrm{HME}$, in Sweden and the UK, for several reasons. Firstly, data on applications to HME subjects are good indications of where social influences shape individual choice around music participation. This helps to outline key differences and similarities in national gender configurations. Secondly, comparing numbers of those who are offered a place compared to those who apply are potential indicators of institutional gender discrimination. This allows for judgment on whether discrimination is more prevalent in certain subjects or nations. It also helps to identify where gender bias in judgments about candidates proficiency may be likely to prevent participation. Thirdly, higher education data are good indicators of who will go on to work with music in as part of a career. The increasing emphasis on formal music education as training for a career in the music industry means that outlining gender divides after compulsory education helps to indicate where divides are likely to exist within the music industries and in professional positions.

In the UK, data on anyone who applied and was offered a place on a HME degree, for the autumn semesters of 2010-2014, were obtained from the University Course Admissions Services (UCAS). ${ }^{7}$ Data include any undergraduate who applied and was accepted to a higher education institution to study any music degree in the $U K^{8}$ at a university. In addition, UCAS Conservatoires (formerly the Conservatoires UK Admissions Service - CUKAS) applications and admissions data, which cover the seven major UK conservatoires (CUKAS 2014), available online, were also examined up until $2013^{9}$ and have been reported on where necessary.

In Sweden, data from the main university admissions service, Universitets och Högskolerådet (UHR) and Universitetskanslerämbetet (UKÄ) were obtained on any undergraduate who applied to and was offered a place, at the second stage of selection (urval 2) on a music-related course or program in the autumn semesters (hösttermin), 20102014. Swedish programs are more closely related to the average three-year UK degrees 


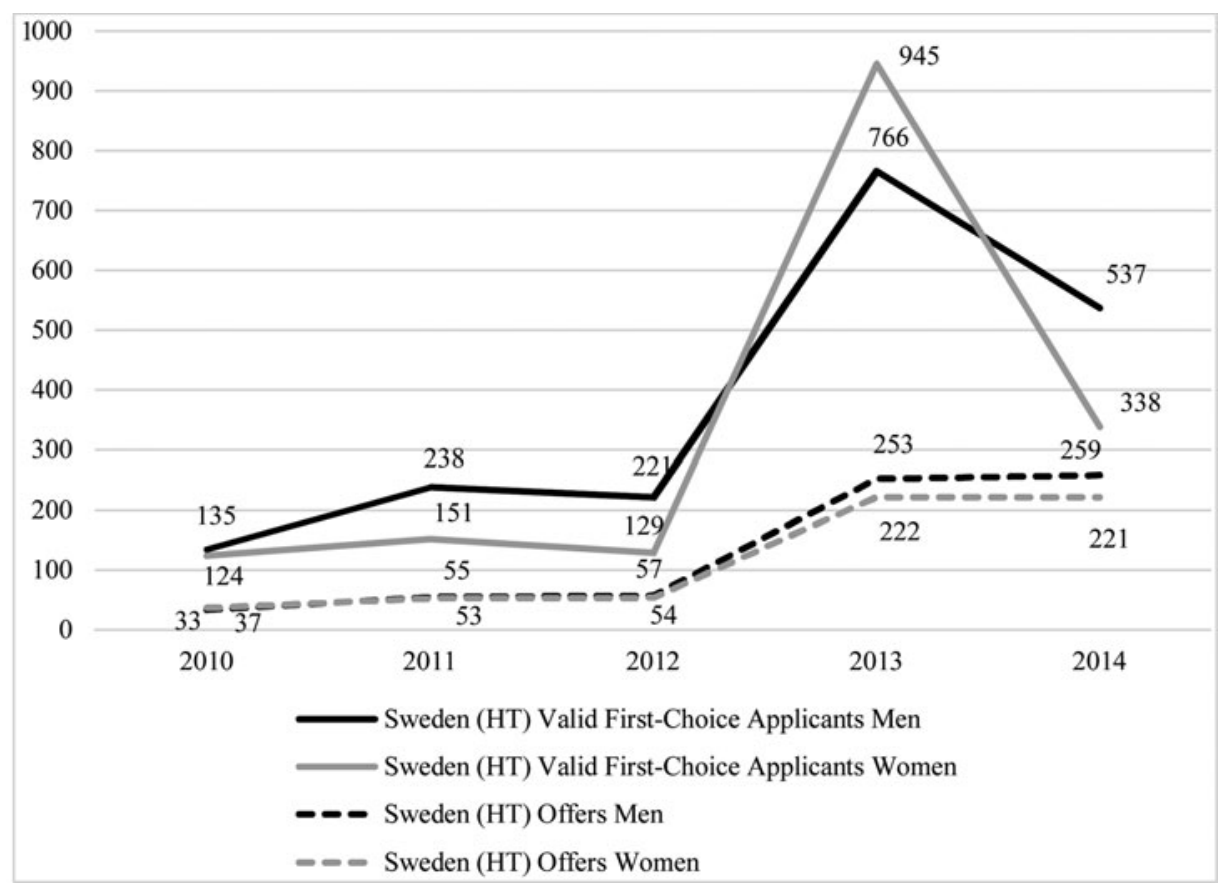

Graph 1. Undergraduate Applications and Offers to Study HME Programs in Universities (Sweden 2010-2014)

(a key exception being music teacher degrees and programs which are often four to five years total in both nations). However it is also possible to take accredited courses at Swedish universities which are generally shorter but still subject to rigorous application procedures. Only data on programs have been included in overall analysis (Graph 1 \& Table 1) whereas data on programs and courses in Sweden have also been included to enable comparisons at subject level (Table 2). Data available in Folkbildningsrådet (FHR) reports have also been noted where appropriate (Table 1). Unless actively stated, both UK and Swedish data all include non-domiciled students and, in the UK, students who were offered a place through 'clearing'. ${ }^{10}$

The period 2010-2014 was chosen because it reflects substantial changes in HE in the UK. These include the trebling of domestic and EU student fees, in England and Wales (from $£ 3,000$ to $£ 9,000$ per year in 2012), lifting the cap on the maximum number of student numbers in 2014 and the removal of upper limits on tuition fees for international students. This meant it was important to first look for any substantial fluctuations in application and/or offer rates, over time, by gender.

After comparing overall application and offer rates to degrees and programs, HME degrees, courses and programs were then grouped according to subject area. This involved generating categories that were sufficiently similar to enable cross national 
Table 1. Number and percentage of applicants in gender category split by country and institution type (Autumn of 2014)

\begin{tabular}{|c|c|c|c|}
\hline & Men & Women & $\%$ Women \\
\hline Folkhögskola - applicants & - & - & - \\
\hline Folkhögskola - offers & 921 & 589 & $39 \%$ \\
\hline $\begin{array}{l}\text { Sweden University and Musikhögskola - } \\
\text { undergraduate program applications (valid } \\
\text { first choice) }\end{array}$ & 537 & 338 & $39 \%$ \\
\hline $\begin{array}{l}\text { Sweden University and Musikhögskola - } \\
\text { undergraduate program offers (valid first } \\
\text { choice) }\end{array}$ & 259 & 221 & $46 \%$ \\
\hline $\begin{array}{l}\% \text { offered a place (within gender category) } \\
\text { Swedish Universities and Musikhögskola }\end{array}$ & $48 \%$ & $65 \%$ & - \\
\hline $\begin{array}{l}\text { UK University - undergraduate program } \\
\text { applicants }\end{array}$ & 22345 & 14830 & $40 \%$ \\
\hline UK University -undergraduate program offers & 5590 & 2960 & $35 \%$ \\
\hline $\begin{array}{l}\text { \% offered a place (within gender category) UK } \\
\text { Universities }\end{array}$ & $25 \%$ & $20 \%$ & - \\
\hline $\begin{array}{l}\text { UK Conservatoire - undergraduate program } \\
\text { applicants }\end{array}$ & 1995 & 3235 & $62 \%$ \\
\hline $\begin{array}{l}\text { UK Conservatoire - undergraduate program } \\
\text { offers }\end{array}$ & 525 & 575 & $52 \%$ \\
\hline $\begin{array}{l}\% \text { offered a place (within gender category) UK } \\
\text { Conservatoires }\end{array}$ & $26 \%$ & $18 \%$ & - \\
\hline
\end{tabular}

music technology courses that also included sound design or production were labelled 'music technology or production'. Performance programs which spanned genres were labelled 'music performance', whilst music management, music industry or music events management were also grouped together. This yielded nice comparative categories and a further four which had no direct equivalent in the other nation, or where student numbers were too low to make reliable comparisons. Analysis involved carrying out $x^{2}$ tests to look for gender differences in application rates in subject areas by nation. This process was then repeated by offer rates. Finally the application-to-offer (OtA) rates within each subject were calculated by gender and these were tested for statistically significant gender differences within each nation. Only data from 2014 has been reported on at subject level.

I stress that, due to cultural differences, course categorisations and higher education selection procedures, data in each country are not always directly identical. For example, jazz and rock programs are often labelled under one umbrella in Sweden, whereas jazz in the UK is usually treated as a distinct program. I also want to stress that these data show applications and offers from the universities, not an exact number of how many students actually enrolled on these courses. Because of national differences in measurement and reporting, these data are intended to be used as informed estimates rather than absolute incidence rates. 
Table 2. Applications and Offers to Specific Courses and Programs by Gender and Nation (Autumn Term 2014)

\begin{tabular}{|c|c|c|c|c|c|c|c|c|c|c|c|c|c|c|c|c|c|c|c|c|}
\hline & \multicolumn{7}{|c|}{ Undergraduate Applications } & \multicolumn{7}{|c|}{ Undergraduate Offers } & \multicolumn{6}{|c|}{ Offers to Applications } \\
\hline & \multicolumn{3}{|c|}{$\begin{array}{c}\text { UK } \\
\text { (Universities) }\end{array}$} & \multicolumn{3}{|c|}{$\begin{array}{c}\text { Sweden (Universities \& } \\
\text { Musikhögskola) }\end{array}$} & \multirow[b]{2}{*}{$\begin{array}{l}p \\
\text { nation }\end{array}$} & \multicolumn{3}{|c|}{$\begin{array}{c}\text { UK } \\
\text { (Universities) }\end{array}$} & \multicolumn{3}{|c|}{$\begin{array}{l}\text { Sweden (Universities \& } \\
\text { Musikhögskola) }\end{array}$} & \multirow[b]{2}{*}{$\begin{array}{l}p \\
\text { nation }\end{array}$} & \multicolumn{3}{|c|}{$\begin{array}{c}\text { UK } \\
\text { (Universities) }\end{array}$} & \multicolumn{3}{|c|}{$\begin{array}{c}\text { Sweden (Universities \& } \\
\text { Musikhögskola) }\end{array}$} \\
\hline & Total & $\begin{array}{l}\text { No. } \\
\text { women }\end{array}$ & $\begin{array}{l}\% \\
\text { women }\end{array}$ & Total & $\begin{array}{l}\text { No. } \\
\text { women }\end{array}$ & $\begin{array}{l}\% \\
\text { women }\end{array}$ & & Total & $\begin{array}{l}\text { No. } \\
\text { women }\end{array}$ & $\begin{array}{l}\% \\
\text { women }\end{array}$ & Total & $\begin{array}{l}\text { No. } \\
\text { women }\end{array}$ & $\begin{array}{l}\% \\
\text { women }\end{array}$ & & $\begin{array}{l}\text { Men } \\
\text { (OtA \%) }\end{array}$ & $\begin{array}{l}\text { Women } \\
\text { (OtA \%) }\end{array}$ & $\begin{array}{l}p \\
\text { gender }\end{array}$ & $\begin{array}{l}\text { Men } \\
\text { (OtA \%) }\end{array}$ & $\begin{array}{l}\text { Women } \\
\text { (OtA \%) }\end{array}$ & $\begin{array}{l}p \\
\text { gender }\end{array}$ \\
\hline Music Tech \& Production & 10925 & 1300 & $12 \%$ & 1693 & 304 & $18 \%$ & $.000^{* *}$ & 6305 & 705 & $11 \%$ & 177 & 35 & $20 \%$ & $.000^{* *}$ & $58 \%$ & $54 \%$ & $.007^{*}$ & $10 \%$ & $12 \%$ & .506 \\
\hline Vocal Performance & 360 & 295 & $82 \%$ & 502 & 373 & $74 \%$ & $.008^{*}$ & 140 & 115 & $82 \%$ & 226 & 180 & $80 \%$ & .557 & $38 \%$ & $39 \%$ & .938 & $36 \%$ & $48 \%$ & $.013^{*}$ \\
\hline $\begin{array}{l}\text { Jazz Performance } \\
\text { (including Rock } \\
\text {-Sweden) }\end{array}$ & 265 & 55 & $21 \%$ & 84 & 34 & $40 \%$ & $.000^{* *}$ & 130 & 25 & $19 \%$ & 39 & 14 & $36 \%$ & $.030^{*}$ & $50 \%$ & $45 \%$ & .548 & $50 \%$ & $41 \%$ & .426 \\
\hline Music Performance & 5585 & 2035 & $36 \%$ & 305 & 171 & $56 \%$ & $.000^{* *}$ & 2935 & 995 & $34 \%$ & 207 & 117 & $57 \%$ & $.000^{* *}$ & $55 \%$ & $49 \%$ & $.000^{* *}$ & $67 \%$ & $68 \%$ & .816 \\
\hline Instrument Specialisation & 470 & 30 & $6 \%$ & 305 & 171 & $56 \%$ & $.000^{* *}$ & 155 & 10 & $6 \%$ & 207 & 117 & $57 \%$ & $.000^{* *}$ & $33 \%$ & $33 \%$ & .966 & $67 \%$ & $68 \%$ & .816 \\
\hline $\begin{array}{l}\text { Music Teaching / } \\
\text { Pedagogy }\end{array}$ & 395 & 230 & $58 \%$ & 457 & 280 & $61 \%$ & .366 & 205 & 140 & $68 \%$ & 266 & 149 & $56 \%$ & $.007^{*}$ & $39 \%$ & $61 \%$ & $.000^{* *}$ & $66 \%$ & $53 \%$ & $.007^{*}$ \\
\hline $\begin{array}{l}\text { Music with Drama or } \\
\text { Theatre }\end{array}$ & 1295 & 940 & $73 \%$ & 155 & 155 & $100 \%$ & $.000^{* *}$ & 620 & 470 & $76 \%$ & 29 & 29 & $100 \%$ & .120 & $42 \%$ & $50 \%$ & .013 & - & $19 \%$ & 1.000 \\
\hline $\begin{array}{l}\text { Music with Music } \\
\text { Business / Industries }\end{array}$ & 3480 & 1520 & $44 \%$ & 969 & 456 & $47 \%$ & .061 & 2020 & 975 & $48 \%$ & 194 & 74 & $38 \%$ & $.007^{*}$ & $53 \%$ & $64 \%$ & $.000^{* *}$ & $23 \%$ & $16 \%$ & $.005^{*}$ \\
\hline Music (Generic) & 11180 & 5780 & $52 \%$ & 412 & 185 & $45 \%$ & $.007^{*}$ & 7130 & 3955 & $55 \%$ & 100 & 40 & $40 \%$ & $.002^{*}$ & $59 \%$ & $68 \%$ & $.000^{* *}$ & $26 \%$ & $22 \%$ & .257 \\
\hline $\begin{array}{l}\text { Chamber / Classical } \\
\text { Music }\end{array}$ & - & - & - & 126 & 83 & $66 \%$ & - & - & - & - & 44 & 30 & $68 \%$ & - & - & - & - & $33 \%$ & $36 \%$ & .689 \\
\hline Music Theory & - & - & - & 1612 & 709 & $44 \%$ & - & - & - & - & 549 & 234 & $43 \%$ & - & - & - & - & $35 \%$ & $33 \%$ & .429 \\
\hline Music with Dance & 2655 & 2325 & $88 \%$ & - & - & - & - & 195 & 130 & $67 \%$ & - & - & - & - & $20 \%$ & $6 \%$ & $.000^{* *}$ & - & - & - \\
\hline Musicology & - & - & - & 1975 & 884 & $45 \%$ & - & - & - & - & 586 & 234 & $40 \%$ & - & - & - & - & $32 \%$ & $26 \%$ & $.005^{*}$ \\
\hline
\end{tabular}

OtA 'Offer to Application' - the percentage of those who applied compared to those who were offered a place on a specific course

* indicates significance at $<.05$

** indicates significance at $<.001$

-no specific course equivalent or too few people to enable comparisons 


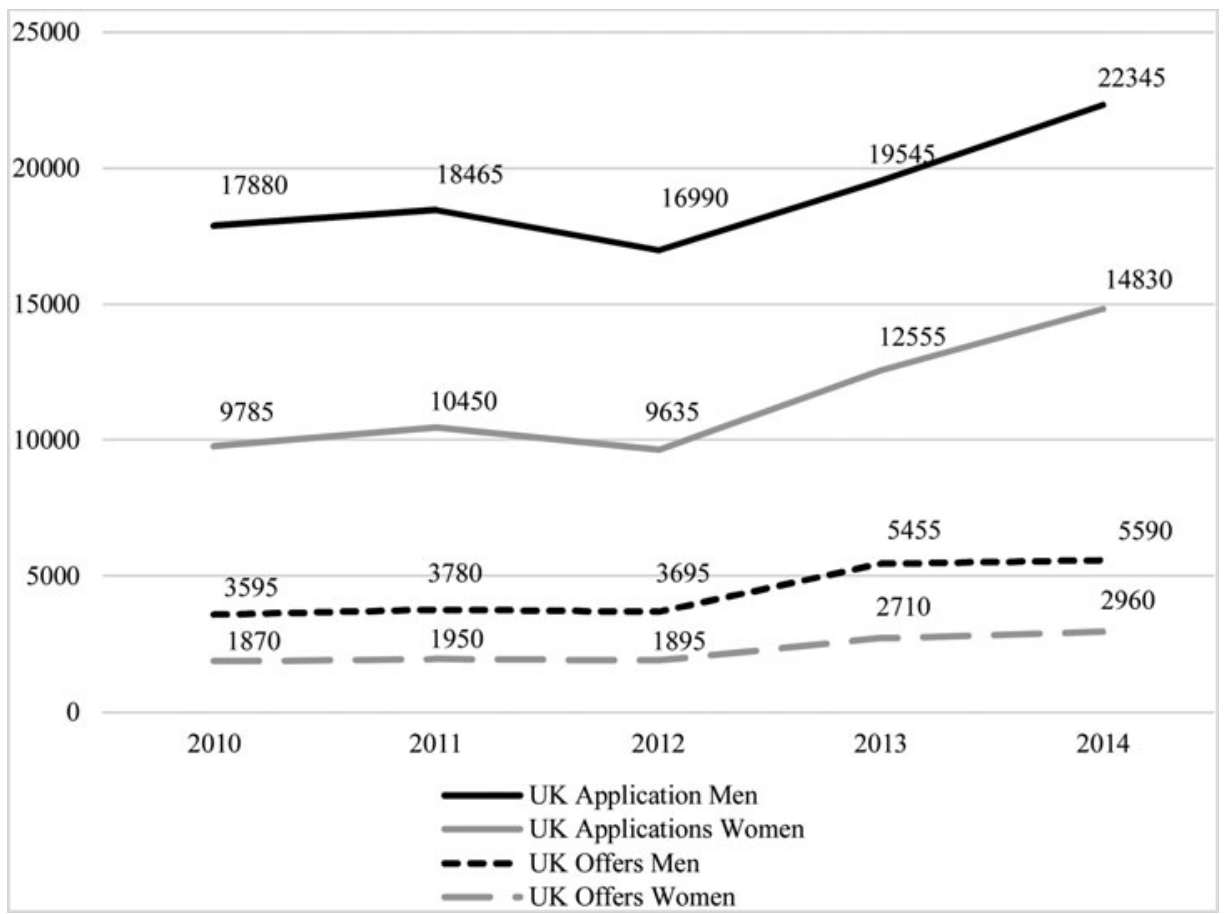

Graph 2. Undergraduate Applications and Offers to Study HME programs in Universities (UK 2010-2014)

\section{Overall Application and Acceptance Rates}

Both nations have similar trends in overall application to higher education courses between male and female genders, with women applying more often than men for any undergraduate program. In Sweden, in 2014, there were 424,844 qualified first choice, higher education applicants, ${ }^{11}$ of which 261,809 (62\%) were women (SCB 2016). In the UK, including clearing, there were a total of 699,685 applicants of which 397,085 (57\%) were women (UCAS 2014: 106).

As Graph 1 shows, overall HME undergraduate program applications have remained comparatively low in Sweden, but increased from 259 qualified, first choice applicants ${ }^{12}$ in 2010 to 875 in 2014 (SCB 2016). This marks a substantial 237\% increase in program applications. The spike in 2013 applications can be explained by the introduction of new music production and theatre programs at degree level, before the high school points required to take the subject were firmly decided. The total number of students enrolled on HME courses at universities and musikhögskola was 5,598 (2,907 men and 2,691 women: see UKÄ 2015: 54).

As Graph 2 shows, despite the increase in tuition fees in 2012, applications to HME degrees in the UK actually increased, amongst men and women, from 27,665 applicants (total) in 2010 to 37,180 in 2014 (UCAS 2015b, p. 9). During the same period, the number of 
students accepted to HME degrees also increased by over 3000, from 5465 to 8550 (UCAS 2015 a, p. 9). This increase can be attributed largely to students being treated as a main source of income for many music departments in the UK, due to substantial government cuts to funding, as well as increasing demands placed on attaining a professional qualification in order to build a career in music (Allsup, 2015). Applicants to UK conservatoires, too, increased by almost 3000, whereas acceptances went up by 36\% from 2010-2014, from 805 to 1095 (UCAS Conservatoires, 2015, p. 42).

As Table 1 demonstrates, when comparing the two countries, in 2014, national differences appeared to have no significant impact on overall application rates by gender at universities $(p=.450)$. Women made up $40 \%$ of HME university applicants, in the UK, and 39\% in Sweden. Folkhögskola music courses in Sweden also had roughly the same gender skew as application rates in both countries. However men made up $65 \%$ of offers in the UK compared to $54 \%$ in Sweden. This means that men have a significantly higher OtA rate in the UK $(p=.000)$ compared to Sweden, where women's was higher $(p=.008)$. Furthermore whilst women made up $62 \%$ of conservatoire applicants in the UK, they made up only $52 \%$ of the total who are accepted (UCAS Conservatoires 2015: 16). In other words, women were significantly less likely than men $(p=.000)$ to be offered a place in UK conservatoires when taking into account proportionately larger numbers of women applicants.

This raises two key issues: firstly, in terms of university and musikhögskola applications, just like the UK (excluding 2013) Swedish HME university programs generally seem to attract fewer women applicants overall. However, when taking into account OtA rates, it seems that women are much less likely to be rejected in Sweden, indicating comparatively lessened institutional discrimination. This is particularly pertinent when considering that students often have to undergo auditions for music courses, which have been prone to gender bias (Goldin \& Rouse, 2000).

Whilst there also seems to be a slowly widening gap in Sweden, these overall trends indicate a broader range of support for women HME candidates in Sweden. As such this may represent a better awareness of gender imbalances in application and selection procedures. This should not be surprising due to the fact that gender equality is explicitly mandated as part of Sweden's 1992 Higher Education Act as well as broader national gender mainstreaming initiatives (Nyberg, 2012). This may therefore explain women's comparatively higher selection rates in Swedish HME compared to the UK.

\section{Subject Application and 0 ffer Rates}

Various authors have demonstrated that the gendering of certain musical subject areas influences music participation in different ways (eg. Abeles, 2009; Armstrong, 2011; Born \& Devine, 2015; Green, 1997; Hall, 2005). It is thus important to look at gender divisions in specific subjects. As Table 2 indicates, when examining application and offer data by course choice, two things emerge. Firstly, in line with the above, there appear to be significant differences between Sweden and the UK in the numbers of men and women applying in many (but not all) of the subjects. Secondly, despite national differences in overall HME application and acceptance rates, several specific subject areas follow relatively similar trends in both nations. This is important in that it highlights that transnational gender 
discourses may influence individual choices across countries, despite formalised gender equality in other areas.

As Table 2 outlines, men are more likely to apply to jazz performance courses, in the UK and to a slightly lesser extent in Sweden, where electric guitar, double bass, drums, sax and trumpet are heavily represented. This divide is also similar at UK conservatoires with women accounting for only $19 \%$ of jazz performance applications, with most of these coming from jazz vocal applications (see CUKAS, 2014, p. 22). These data are supported by much of the academic work around gender divisions in instrument choice, in secondary schools in Anglophone nations (Abeles, 2009; Wych, 2012), as well as official reports in schools from both nations (ABRSM, 2014; Ungdomstyrelsen, 2014). This suggests that gender divisions in instrument selection, and activity in secondary education, are further amplified in HME in both the UK and Sweden.

As the data also clearly indicate, women are more likely to apply and make up the larger proportion of all vocal course offers and applications in both nations. Vocal courses, and singing generally, are one area where women have consistently been much more highly represented than men in Western and global Northern countries. This has often been explained as a result of discursive links between femininity and the body (Green, 1997) and a rejection of singing by young men as a 'feminine' activity (see Hall, 2005). However, in Sweden, men are significantly more likely to apply to vocal courses in than the UK $(p=.008)$, but show significantly lower levels of offers to application rates in comparison to women $(p=.013)$. The UK has virtually the same ratios of offers to applications for men and women $(p=.938)$. On the one hand, in terms of student choices, this could indicate less of a clear binary around singing as a 'feminine' or 'masculine' activity in Sweden. On the other, it suggests that institutionalised gender norms in Sweden may still influence admissions to singing courses.

Music education / teaching courses also saw considerably higher numbers of women in both Sweden and the UK apply. This did not differ significantly by nation. However what is particularly interesting is that a significantly larger proportion of men who applied in Sweden were likely to be accepted than women. In the UK, the situation was the exact reverse. A particularly strong perception in the UK surrounding the 'feminisation of teaching' (Skelton, 2012) and national gendered differences in cultures of professionalism (Drudy, 2008, p. 318), may partially explain differences here. Similarly, gender-mainstreaming agendas in Sweden, interpreted as equal numbers of men and women, may also explain men's greater representation than in the UK. Yet given that overall applications to music education courses and programs have declined significantly in Sweden, this difference is worth exploring further.

In the UK, men were significantly more likely to make up the majority of applications and offers in music performance programs, than in Sweden. Differences were even more pronounced when looking at instrument specialisation. This was in marked contrast to generic music courses and programs (without a specific focus on performance, instrumentation or other specialisations) where women had a higher OtA rate than men. Perhaps one of the most striking findings is that, in the UK, women made up only $6 \%$ of applications to university programs with a focus on a specific instrument (see Instrument Specialisation) but over $56 \%$ of program and course applications in Sweden. The gender differences between 'generic' and 'specialised' courses at UK Universities are particularly 
important because, as noted above, professionalisation and university accreditation are increasingly being treated as a route into careers as musicians (Allsup, 2015). This suggests that gender imbalances in application and offer rates will continue to, or perhaps even further exacerbate, inequalities in the music industries and professions in the UK especially.

The impact of an instrumentalised rationality on music education can also be seen through the growth in education directly focused on music management, music business and the music industries. As Table 2 shows, similar numbers of men and women apply for music industry/business courses in the UK and Sweden (c.45\% women). Yet whilst women have an OtA rate of $68 \%$ in the UK (significantly higher than men's 53\%) the reverse was true in Sweden where $23 \%$ of men who applied were offered a place, compared to only $16 \%$ of women. This raises particular questions about the type of occupations that women who go into the music industries may end up in, in both countries.

Music technology and production courses, especially, see overwhelmingly more applicants who are men in both Sweden and the UK. Women appeared significantly more likely to apply in Sweden than the UK $(p=.000)$ but still only made up $18 \%$ of total applications and $20 \%$ of all offers in 2014. The large disparity in application rates in both countries can partially be explained by longstanding symbolic links between technology and masculinity whereby controlling 'natural' objects through the application of 'rational' calculated judgment have become connected to images of masculinity (Farrugia, 2012). A belief, therefore, that boys are inherently better at or more interested in using technology leads to unequal treatment in music classrooms (Armstrong, 2011). Yet it is also important to note that women in the UK were significantly more $(p=.007)$ likely to have their applications to music tech and production courses rejected than in Sweden. In Sweden, the disparities could be better explained by the volume of applications from men and there were no significant differences $(p=.506)$ around offer rates on the basis of gender.

Music tech and production courses are the fastest growing HME subject areas in both countries. Given the changing nature of the music industries and digital music media, as well as Sweden's place in the global music industries, gender disparities on these courses are of particular concern (see also Born \& Devine, 2015). The role of producers, studio engineers and sound technicians increasingly affords opportunities inside and outside the music industries to those with an in-depth knowledge of production techniques; largely because self-production drives down A\&R development costs (Wikström, 2009). Unequal numbers of men and women in music tech and production courses will, therefore, invariably translate to wage inequalities and representation within music industries and scenes later on in people's musical lives and careers.

\section{Discussion: The Implications for Gender Equality in HME}

The question is to what extent these trends can help to understand the different forms that gender inequality takes in HME. Crucially, by focusing on what the data reveal as well as its limitations, it is important to consider how to gender equality strategies should best be implemented and what the potential barriers to their implementation may be. 
These data indicate that Sweden fares better than the UK in encouraging women's participation overall in HME. However they also suggests that there are key similarities in music subject choice in both countries. These similarities indicate the prevalence of transnational gendered discourses with regard to instrument selection and choice of musical activities. Importantly, adopting popular music curricula in secondary education, as in the case of Sweden, does not invariably lead to '50/50' representation in many cases (see Georgii-Hemming \& Westvall, 2010). Gendered imbalances are not only a problem in 'classical' activities but 'popular' music too; something which feminist authors have repeatedly observed outside of formal education (Björck, 2013; Davies, 2001; Leonard, 2007; O'Meara, 2003).

Nevertheless, treating gender equality only as a matter of quantitatively equal, homogenous groups of men and women is problematic (Koskoff, 2014). Understanding equality as equal numbers of binary sexes overlooks specific forms of discrimination facing trans*, queer and non-binary individuals (Hines, 2013; SFQ, 2015) and pluralistic understandings of gendered expression and identity (Halberstam, 2012). Gender also intersects with dynamics of nationality, class and ethnicity (Nayak \& Kehily, 2013). This means that gender inequalities in HME, should also not be thought of as simply concerned with dichotomies of men/women or masculinity/femininity (Bergonzi, 2015).

There is evidence that class and ethnicity, particularly, impact heavily on gendered application, discrimination and selection. In UK conservatoires, class still proves to be a huge barrier to admittance (UCAS Conservatoires, 2015, p. 27) and shapes gendered HME choices (Born \& Devine, 2015). Yet whilst women are less likely to be accepted overall to undergraduate UK music courses, no Black (an imperfect label in itself) UK-domiciled women or men were admitted to any UK conservatoire in 2011, 2012 or 2013 (CUKAS 2014: 21$).{ }^{13}$ This is, quite simply, astonishing.

A focus on race and ethnicity are equally important in Sweden. Gender mainstreaming approaches, understood as equal numbers of men and women, have historically obscured intersectional forms of discrimination (de los Reyes, 2016, pp. 36-38), particularly affecting Swedish Sami and Roma women (Alex \& Lehti, 2013). Yet neither nation provided microlevel data on applications or offers and Sweden does not capture data on ethnicity, making it impossible to compare how intersectional gender currently is in HME.

Vitally, intersectionality means both recognising intersectional representation in existing selection procedures and questioning how aesthetic traditions are represented in HME and within subjects. An 'additive' approach to intersectional representation (YuvalDavis, 2006), alone, does not disrupt the classed, gendered and ethnic hierarchies on which institutional aesthetic priorities are based (Bradley, 2005). At its most trivial, it suggests that getting more women of colour to play Bach and Beethoven is more important than reformulating the terms by which patriarchal canons are considered benchmarks of excellence (Macarthur, 2010).

Recognising that gender is intersectional also means being attentive to intersectionally gendered histories. For instance, as Pelligrinelli (2008) notes, an emphasis on teaching jazz's instrumental history has often been at the expense of its historic vocal traditions where women have historically been well-represented. This doubly obscures women of colour's 
contributions as both vocalists and instrumentalists. As such, jazz may continue to appeal predominantly more to certain kinds of instrumentalists (among whom men are already heavily-represented). Intersectional, postcolonial and de colonial understandings of gender inequalities in education are all therefore essential in challenging certain epistemological assumptions (see also Mirza \& Jospeh, 2010).

Crucially, as Macarthur (2010) points out, the idea of making women more 'competitive', does not represent equality. In doing so, activities where women are visible (singing for example) are framed as barriers to participation, rather than the denigration of musical activities or aesthetic traditions where women of different backgrounds are more visible (see Railton, 2001). Conversely, '50/50' approaches may actively lead to preferential treatment of men in areas where women are now better represented, despite historical exclusion; the so-called missing males problem in choirs for example ( $\mathrm{O}^{\prime}$ Toole, 1998). In fact, in the UCAS Conservatoires annual report, women's significantly lower OtA rate is argued to not represent gender discrimination because roughly the same percentage of women and men are accepted (UCAS Conservatoires, 2015, p. 23). This clearly misses the initial purpose of gender mainstreaming agendas.

To this end, gender equality must be concerned with challenging informally discriminatory practices within certain masculinist environments as well as building respect for intersectionally gendered aesthetic traditions. This also means gender equality should involve engaging and challenging men around questions of privilege rather than encouraging women to better compete in men-dominated spaces. Institutional support for pluralist, intersectional models, in both gendered expression and selection criteria, are therefore vital in tackling inequalities.

\section{HME, Gender and Neoliberalism}

Intersectional gendered norms undoubtedly unconsciously influence HME subject choices (Bogdanovic 2015). This means HME in both nations is in a difficult position in that decisions around instrument and activity specialisation have often already been made by the time students apply to universities. In societies where universities are increasingly seen as spaces to 'train' people for careers in specific industries, there is less space for experimentation and time to develop other interests as well as psychological pressures to make the 'right' choice (Allen et al., 2013). Both nations are also increasingly financially reliant on students and encouraged to respond to them as consumers who are presumed to know what is best for them (Naidoo \& Williams 2015).

Such changes have occurred, primarily, due to a broader neoliberalisation of higher education (Shore, 2010), a central feature of which has been the top-down imposition of free-market mechanisms on previously public institutions. As Radice (2013) notes, in the UK since the 1970s, neoliberalisation of higher education has led to resources being allocated dependent on student numbers and 'target-driven' metrics (Radice, 2013, p. 408). Simultaneously, universities have been encouraged to operate as businesses, whereby departments compete for funding in order to demonstrate their 'economic viability', rather than being regarded for their intrinsic social value (Collini, 2012). Similar changes have also taken place in Sweden (Beach, 2013). 
With respect to teaching, Swedish universities are paid by the government, per student, in two instalments; the first after student admission and the second upon course/program completion. In the UK, the government removed almost $£ 1$ bn from the Higher Education Funding Council for England (HEFCE) budgets, in 2010 in a deliberate attempt to establish markets in HE. Given that there is comparatively much less research funding for the arts, reliance on funding from teaching is a pressing concern in both nations for similar reasons. HME in both is thus increasingly dependent not only on getting quantitatively more students in but keeping those students happy enough to stay to completion.

These data, presented above, therefore, raise particular issues around how gendered patterns in subject choice relate to universities' willingness to address and change gendered attitudes, rather than simply respond to 'consumer' choice. If undergraduate choices are already gendered by nature of specialisation in particular subjects and instruments, ignoring or discounting their views about their preferred way of learning is both pedagogically unsound and also ethically dubious. Yet framing courses in deliberately 'gender-subversive' ways carry potentially financially catastrophic consequences for music departments; if students find the courses unappealing they may choose not to study, to change or discontinue their studies. Thus the scope of individual HME departments to commit to meaningful change may be severely restricted in both nations.

On the other hand, accepting a neoliberal hegemony that places student choice at the centre of educational systems, without questioning those choices, also risks reinforcing pre-existing gender inequalities. Emancipatory, feminist notions of 'freedom to choose' therefore become co-opted by neoliberal rhetoric to mean 'unlimited choice' without thinking about how those choices are socially influenced (Fraser, 2013). Such a view reproduces the idea that the role of education is to cater to individual choice, rather than acting as a force for changing perceptions of gender in music (Bergonzi, 2015).

Drastic changes to UK higher education, particularly, appear to have promoted an increasing instrumentalisation of HME choices. This is apparent in the growth, especially, in career-oriented subject choices. For instance music industries-related, music performance and music technology courses. This has also been seen, to a certain extent, in Sweden with a proportionately large spike in applications from 2013-2014 linked to music production and tech programs. The slowly increasing gap between men's and women's applications and offer rates, in light of increasing marketisation, should also be taken very seriously. However, the fact that the UK has much higher acceptance rates generally than Sweden across most of the subjects (over four times higher in some subjects) suggests that intense neoliberalisation, financial reliance on students and associated presumptions of consumer choice, may in fact be more of a barrier to intervening in or changing gendered choices in $\mathrm{HME}$. A treatment of gender inequalities in $\mathrm{HME}$, which are rooted in material, transnational analyses, as well as focusing on immediate institutional contexts or interpersonal groupdynamics, are therefore vital.

\section{Conclusion}

It is tempting to argue that Sweden is far more progressive than the UK when it comes to HME. A more state-based, formalised gender equality approach seems to translate to fewer gender differences. The data offered here would indicate that state intervention in 
higher education and through cultural policy leads to greater representation of women in many different areas of music education. Yet as this article has also outlined whilst there is a problem with quantitative skews toward men in many HME courses, this alone is not necessarily an indicator of inequalities. The data also indicate the presence of cross national consistencies and that Sweden is also perhaps not as equal in some areas as others, in addition to a widening OtA ratio amongst women on HME programs.

Instead of treating 'better' or 'worse' just in terms of statistical representation, it is necessary to seriously rethink what gender equality really should look like in HME, with a specific focus on the role of HME institutions in relation to globalised, neoliberal societies. This must be done in tandem with an intersectional understanding of gender. As also suggested, socio-economic factors, race and ethnicity are clear barriers to participation in HME in the UK. These are almost completely absent from Swedish debates on gender equality (de los Reyes, 2016). The importance of recognising interlocking, multiple, forms of discrimination are especially pertinent in two societies which are seeing an increasing pervasiveness of racism and xenophobia in public debate as well as widening socio economic inequalities. This does not detract from the existence of gendered forms of discrimination, but enhances an awareness of complexity in future strategies for tackling gender inequality in music education.

This article cannot do justice to the complexity of debates around gender in music or the excellent work already being done to address some of the issues, raised here. However, looking at application and admission data between the two nations, it is clear that similar trends in the types of HME subjects exist in both the UK and Sweden by gender. I would suggest that this attests to the influence of global, transnational discourses around music and gender, as well as how the influence of Westernised gender norms continue to influence gender divisions in terms of participation. This raises particular concerns about how to implement strategies to tackle divisions in HME at local and national levels, especially where years of gendered socialisation have influenced course and program participation.

\section{Notes}

1 http://www.kulturskoleradet.se/sv/om-smok/historic

2 The recent curriculum review insists on teaching students as young as 6 the work of 'great composers' and to recognise: 'pitch, duration, dynamics, tempo, timbre, texture, structure and appropriate musical notations' (https://www.gov.uk/government/uploads/system/uploads/ attachment_data/file/239037/PRIMARY_national_curriculum_-_Music.pdf)

3 The government previously allocated funding for 'non-core' (extracurricular) music activities directly from the Department of Education (http://www.telegraph.co.uk/culture/music/music-news/ 10895160/Our-music-education-is-being-killed-by-cuts-and-cock-ups.html; http://www.artscouncil.org.uk/music-education/music-education-hubs).

4 Costing an average of $£ 30$ per-hour, outside of London (http://www.ism.org/ advice/music-teacher-fees).

5 Nearly half of all children who had private lessons came from AB socio-economic groups (http://gb.abrsm.org/en/making-music/4-the-statistics).

6 Sweden has 14 universities and a further 16 'högskola' that have the 'right to examine' (examensrätt), compared with 163 accredited institutions in the UK.

7 2014/15 was the most recent academic year for which comprehensive data were available. 
8 To avoid identification, UCAS does not release data on courses and degree programs where less than 5 people are registered. Data are also rounded to the nearest 5 (why, I cannot understand).

9 Detailed data on instruments, applications, offers and demographics were freely available in every previous CUKAS report until 2015. However this has very recently been changed and now information on specific instruments by gender is grouped by instrument type.

10 'Clearing' is the name given to the process whereby UK applicants who do not achieve their expected grades may still be offered a place on a degree program.

11 This figure was obtained combining Swedish domiciled and non-domiciled first cycle applicants.

12 In Sweden, in official reports, a screening process is applied to determine whether applicants have enough 'high school points' to be eligible for the program. This means that the total number of applicants is much higher but they are not included in the reports.

13 Amongst the 15, 36 and 49, respectively, who applied.

\section{References}

ABELES, H. (2009) Are Musical Instrument Gender Associations Changing? Journal of Research in Music Education, 57(2), 127-139.

ABRSM (2014) Making Music: Teaching, Learning and Playing in the UK, A Collaborative Research Project. London: Associated Board of the Royal Schools of Music.

ALEX, L. \& LEHTI, A. (2013) Experiences of well-being among Sami and Roma women in a Swedish context. Health Care for Women International, 34(8), 707-726.

ALLEN, K., QUINN, J., HOLLINGWORTH, S. \& ROSE, A. (2013) Becoming employable students and 'ideal' creative workers: exclusion and inequality in higher education work placements. British Journal of Sociology of Education, 34(3), 431-452.

ALLSUP, R. E. (2015) The eclipse of a higher education or problems preparing artists in a mercantile world. Music Education Research, 17(3), 251-261.

ARMSTRONG, V. (2011) Technology and the Gendering of Music Education. Aldershot: Ashgate.

ARREMAN, I. E. \& HOLM, A. S. (2011) Privatisation of public education? The emergence of independent upper secondary schools in Sweden. Journal of Education Policy, 26(2), 225-243.

BEACH, D. (2013) Changing higher education: Converging policy-packages and experiences of changing academic work in Sweden. Journal of Education Policy, 28(4), 517-533.

BERGMAN, Å. (2014) Genuskonstruktioner när rockbandet utgör normen. In C. Ericsson \& M. Lindgren (Eds.), Perspektiv på Populärmusik och Skola. Lund: Studentlitteratur.

BERGONZI, L. S. (2015) Gender and Sexual Diversity Challenges (for Socially Just) Music Education. In C. Benedict, P. Schmidt, G. Spruce and P. Woodford (Eds.), The Oxford Handbook of Social Justice in Music Education.

BJÖRCK, C. (2013) A Music Room of One's Own: Discursive Constructions of Girls-only Spaces for Learning Popular Music. Girlhood Studies, 6(2), 11-29.

BOGDANOVIC, D. (2015) Gender and Equality in Music Higher Education. National Association for Music in Higher Education.

BORGSTRÖM-KÄLLÉN, C. (2014) När Musik gör Skillnad: Genus och Genrepraktiker i Samspel. Dissertation. Göteborgs Universitet.

BORN, G. \& DEVINE, K. (2015) Music technology, gender, and class: Digitization, educational and social change in Britain. Twentieth-Century Music, 12(2), 135-172.

BRADLEY, D. (2005) Music Education, Multiculturalism, and Anti-Racism - can we talk? Action, Criticism \& Theory for Music Education, 5(2), 2-30.

BRÄNDSTRÖM, S., SÖDERMAN, J. \& THORGERSEN, K. (2012) The double feature of musical folkbildning: Three Swedish examples. British Journal of Music Education, 29(1), 65-74. 
CITRON, M. (1993) Gender and the Musical Canon. Champaign, IL: University of Illinois Press.

COLLINI, S. (2012) What are Universities For? London: Penguin Books.

CROMPTON, R. (2001) Gender restructuring, employment and caring. Social Politics: International Studies in Gender, State \& Society, 8(3), 266-291.

CUKAS (2014) Conservatoires UK Annual Report: 2013 Entry Cycle. London: Conservatoires UK Admission Service.

DAVIES, H. (2001) All rock and roll is homosocial: The representation of women in the british rock music press. Popular Music, 20(3), 301-319.

DE LOS REYES, P. (2016) When feminsim became gender equality and anti-racism turned into diversity management. In L. Martinsson, G. Griffin and K. Nygren (Eds.), Challenging the Myth of Gender Equality in Sweden. (pp. 23-47). Bristol: Policy Press.

DONZE, P. L. (2010) Heterosexuality is totally metal: Ritualized community and separation at a local music club. Popular Music Studies, 22(3), 259-282.

DRUDY, S. (2008) Gender balance/gender bias: the teaching profession and the impact of feminisation. Gender and Education, 20(4), 309-323.

FARRUGIA, R. (2012) Beyond the Dance Floor: Female DJs, Technology, and Electronic Dance Music. Bristol: Intellect.

FRASER, N. (2013) The Fortunes of Feminism: From State Managed Capitalism to Neoliberal Crisis. London: Verso.

GAVANAS, A. \& REITSAMMER, R. (2013) DJ Technologies, social networks, and gendered trajectories in European DJ cultures. DJ Culture in the Mix: Power, Technology, and Social Change in Electronic Dance Music. London: Bloomsbury.

GEORGII-HEMMING, E. \& WESTVALL, M. (2010) Music education - a personal matter? Examining the current discourses of music education in Sweden. British Journal of Music Education, 27(1), 21-33.

GOLDIN, C. \& ROUSE, C. (2000) Orchestrating impartiality: The impact of 'blind' auditions on female musicians. The American Economic Review, 90(4), 715-741.

GOV.UK. (2016). Education and Training Statistics for the UK: 2016. Available at <https://www. gov.uk/government/statistics/education-and-training-statistics-for-the-uk-2016>[Accessed 6th February 2017]

GREEN, L. (1997) Music, Gender and Education. Cambridge: University of Cambridge Press.

GREEN, L. (2002) How Popular Musicians Learn: A Way Ahead for Music Education. London: Ashgate.

HALBERSTAM, J. (2012) Global female masculinities. Sexualities, 15(3-4), 336-354.

HALL, C. (2005) Gender and boys' singing in early childhood. British Journal of Music Education, 22(01), $5-20$.

HALLAM, S. \& CREECH, A., Eds. (2010). Music Education in the 21st Century in the United Kingdom: Achievements, Analysis and Aspirations. London: UCL IOE Press.

HEARN, J. (2015) Men of the World: Genders, Globalizations, Transnational Times. London: Sage.

HEARN, J., NORDBERG, M., ANDERSSON, K., BALKMAR, D., GOTTZÉN, L., KLINTH, R., PRINGLE, K. \& SANDBERG, L. (2012) Hegemonic masculinity and beyond: 40 years of research in Sweden. Men and Masculinities, 15(1), 31-55.

HECLO, H. (2010) Modern Social Politics in Britain and Sweden: From Relief to Income Maintenance. Colchester: ECPR Press.

HINES, S. (2013) Gender Diversity, Recognition and Citizenship. Basingstoke: Palgrave Macmillan.

KILKEY, M. (2006) New Labour and reconciling work and family life: Making it fathers' business? Social Policy and Society, 5(02), 167-175.

KOSKOFF, E. (2014) A Feminist Ethnomusicology: Writings on Music and Gender Champaign, IL: University of Illinois Press.

KVARNHALL, V. (2015) Pojkars Musik, Reproduktionens Tystnad. En Explanatorisk Studie av Pojkars Förhållningssätt till Populärmusicerande. Diss. Örebro University. 
LEONARD, M. (2007) Gender in the Music Industry: Rock Discourse and Girl Power. Aldershot: Ashgate. MACARTHUR, S. (2010) Towards a Twenty-first-century Feminist Politics of Music. Farnham: Ashgate.

MACARTHUR, S. (2014) The woman composer, new music and neoliberalism. Musicology Australia, 36(1), $36-52$.

MARTINSSON, L., GRIFFIN, G. \& NYGREN, K. G. (2016) Challenging the Myth of Gender Equality in Sweden. Bristol: Policy Press.

MCCLARY, S. (1991) Feminine Endings: Music, Gender and Sexuality Minneapolis: University of Minnesota Press.

MIRZA, H. S. \& JOSPEH, C. (2010) Black and Postcolonial Feminisms in New Times: Researching Educational Inequalities. London: Routledge.

NAIDOO, R. \& WILLIAMS, J. (2015) The neoliberal regime in English higher education: Charters, consumers and the erosion of the public good. Critical Studies in Education, 56(2), 208-223.

NAYAK, A. \& KEHILY, M. (2013) Gender, Youth and Culture: Global Masculinities and Femininities. Basingstoke: Palgrave Macmillan.

NYBERG, A. (2012) Gender equality policy in Sweden: 1970s-2010s. Nordic Journal of Working Life Studies, 2(4), 67-84.

O'MEARA, C. (2003) The Raincoats: breaking down punk rock's masculinities. Popular Music, 22(3), 299313.

O'TOOLE, P. (1998) A missing chapter from choral methods books: How choirs neglect girls. The Choral Journal, 39(5), 9-32.

PELLIGRINELLI, L. (2008) Separated at 'birth': Singing and the history of jazz. In N. Rustin \& S. Tucker (Eds.), Big Ears: Listening for Gender in Jazz Studies. (pp.31-47). Durham NC: Duke University Press.

PIKETTY, T. (2014) Capital in the Twenty-First Century. (trans) A. Goldhammer. Cambridge MA: The Belknap Press.

RADICE, H. (2013) How we got here: UK higher education under neoliberalism. ACME: An International E-Journal for Critical Geographies, 12(3), 407-418.

RAILTON, D. (2001) The gendered carnival of pop. Popular Music, 20(3), 321-331.

REGERINGSKANSLIET. (2014). Gender Mainstreaming: Fact Sheet. Available at<http://eige.europa.eu/ sites/default/files/documents/05\%20Fact $\% 20$ sheet $\% 20-\% 20$ gender $\% 20$ mainstreaming $\% 20$ in $\%$ 20Sweden.pdf $>$ [Accessed 8th November 2016]

ROINE, J. \& WALDENSTRÖM, D. (2012) On the role of capital gains in Swedish income inequality. Review of Income and Wealth, 58(3), 569-587.

SCB. (2015) Yearbook of Educational Statistics 2015. Available at <http://www.scb.se/Statistik/ _Publikationer/UF0524_2014A01_BR_UF01BR1401.pdf> [Accessed 5th February 2017]

SCB. (2016) Applicants and Admitted to Higher Education at First and Second Cycle Studiesz. Available at <http://www.scb.se/en_/Finding-statistics/Statistics-by-subject-area/Education-and-research/Highereducation/Applicants-and-admitted-to-higher-education-at-first-and-second-cycle-studies/> [Accessed 4th January 2016]

SFQ. (2015) Avslöja Heteronormen! Available at <http://hbtqstudenterna.se/wordpress/wp-content/uploads/ 2013-avsloja-heteronormen-gu-chalmers.pdf> [Accessed 21 st April 2016]

SHORE, C. (2010) Beyond the multiversity: Neoliberalism and the rise of the schizophrenic university. Social Anthropology, 18(1), 15-29.

SKELTON, C. (2012) Men teachers and the 'feminised' primary school: a review of the literature. Educational Review, 64(1), 1-19.

TOWNS, A., KARLSSON, E. \& EYRE, J. (2014) The equality conundrum: Gender and nation in the ideology of the Sweden Democrats. Party Politics, 20(2), 237-247.

U.N. (2014) United Nations Development Programme Human Development Reports: Gender Inequality Index. Available at <http://hdr.undp.org/en/content/table-4-gender-inequality-index>[Accessed 1st March 2015] 
UCAS. (2014) UCAS End of Cycle Report 2014. Available at <https://www.ucas.com/ sites/default/files/2014-ucas-end-of-cycle-report-v2.pdf>[Accessed 5th September 2015]: UCAS Analysis and Research.

UCAS. (2015a) End of Cycle 2015 Data Resources: Acceptances by Detailed Subject Group and Sex. Available at <https://www.ucas.com/sites/default/files/eoc_data_resource_2015-dr3_019_01.pdf> [Accessed 2nd February 2016]

UCAS. (2015b) End of Cycle 2015 Data Resources: Applications by Detailed Subject Group and Sex. Available at <https://www.ucas.com/sites/default/files/eoc_data_resource_2015-dr3_019_03.pdf> [Accessed 2nd February 2016]

UCAS CONSERVATOIRES. (2015) End of Cycle Report 2014. Available at $<$ https://www.ucas.com/sites/default/files/ucasconservatoires_eoc2014.pdf>[Accessed 5th September 2015]: UCAS Analysis and Research

UKÄ. (2015) Higher Education: Students and graduates at first and second cycle studies 2014/15. Available at <http://www.uka.se/download/18.1a00c25e15409a6215693/1460539514557/rapportstudenter-och-examinerade-p\%C3\%A5-grundniva-och-avancerad-niva-2014-15.pdf $>$ [Accessed 5th September 2015]

UNGDOMSTYRELSEN (2014) När, Var, Hur, om Ungas Kultur: En Analys av Ungas Kulturutövande på Fritiden. Stockholm: Ungdomstyrelsen.

WEST, A. (2014) Academies in England and independent schools (fristående skolor) in Sweden: Policy, privatisation, access and segregation. Research Papers in Education, 29(3), 330-350.

WIKSTRÖM, P. (2009) The Music Industry. Cambridge: Polity Press.

WOMEN'S BUDGET GROUP (2016) A Cumulative Gender Impact Assessment of Ten Years of Austerity Policies: A Briefing from the UK Women's Budget Group on the Cumulative Distributional Effects of Cuts in Public Spending and Tax Changes on Household Income by Gendered Types over the Period 2010-20. United Kindom: Women's Budget Group.

WORLD ECONOMIC FORUM. (2014) The Global Gender Gap Report 2014. Available at $<$ http://reports.weforum.org/global-gender-gap-report-2014/> [Accessed 18 August 2015]

WYCH, G. (2012) Gender and instrument associations, stereotypes and stratification, a literature review. National Association for Music Education, 30(2), 22-31.

YUVAL-DAVIS, N. (2006) Intersectionality and feminist politics. European Journal of Women's Studies, 13(3), 193-209.

Sam de Boise is a postdoctoral researcher in the School of Music, Theatre and Art at Örebro University, Sweden. His current research looks to understand gender inequalities in music engagement by comparing the UK and Sweden. Other interests include social theory, music technology and digitalisation, neoliberalism and the intersections of class and music practices. He is also the author of Men, Masculinity, Music and Emotions (2015 Palgrave Macmillan). 